\title{
The different characteristics of the recent eruptions of Fernandina and Sierra Negra volcanoes (Galápagos, Ecuador)
}

\author{
Francisco Vasconez ${ }^{\star \alpha}$, Patricio Ramón ${ }^{\alpha}$, Stephen Hernandez ${ }^{\alpha}$, Silvana Hidalgo $^{\alpha}$, \\ Benjamin Bernard ${ }^{\alpha}$, Mario Ruiz $^{\alpha}$, Alexandra Alvarado ${ }^{\alpha}$, Peter La Femina ${ }^{\beta}$, Gorki Ruiz ${ }^{\gamma}$ \\ ${ }^{\alpha}$ Instituto Geofísico, Escuela Politécnica Nacional. Quito, Ecuador. \\ $\beta$ The Pennsylvania State University. Pennsylvania, USA. \\ $\gamma$ Universidad Central del Ecuador. Quito, Ecuador.
}

\begin{abstract}
After eight years of quiescence, Fernandina volcano experienced two short-lived eruptions, on 4 September 2017 and 16 June 2018. The eruptions were characterized by very short periods of unrest that started a few hours before the initiation of the eruptive activity. On the other hand, Sierra Negra volcano (Isabela Island) began a new eruptive period on 26 June 2018, after almost one year of persistent unrest characterized by an increase in the magnitude and number of seismic events and more than 5 meters of uplift since its last eruption in 2005. The Sierra Negra and Fernandina eruptions were located in remote zones where access is extremely complex. Thus, satellite images complement the continuous monitoring data of the Instituto Geofísico (IG-EPN) with remote observations and allow rapid response mapping in order to identify the areas affected by the lava flows. Finally, the aim of this Report is to encourage other scientists to investigate the behaviors of both pre-eruptive and eruptive periods registered during these eruptions.
\end{abstract}

\section{RESUMEN}

Después de ocho años de reposo, el volcán Fernandina experimentó dos periodos eruptivos de corta duración, el 4 de Septiembre del 2017 y el 16 de Junio del 2018. Dichas erupciones se caracterizaron por etapas muy cortas de agitación que iniciaron pocas horas antes de la erupción. Por otro lado, el volcán Sierra Negra, localizado en la Isla Isabela, inició un nuevo periodo eruptivo el 26 de Junio del 2018, después de casi un año de persistente agitación caracterizada por el incremento en la magnitud y número de eventos sísmicos y más de cinco metros de levantamiento del piso de la caldera desde su última erupción en 2005. Las erupciones de Sierra Negra y Fernandina se localizaron en zonas remotas, donde el acceso es extremadamente difícil. Es así que, imágenes satelitales complementaron el monitoreo continuo realizado por el Instituto Geofísico (IG-EPN) y permitieron identificar las zonas afectadas por los flujos de lava. Finalmente, uno de los propósitos de este reporte es alentar a otros científicos a investigar el funcionamiento de estos volcanes durante las etapas pre-eruptivas y eruptivas registradas.

Keywords: Galapagos; Sierra Negra; Fernandina; Remote sensing; Monitoring; Hazard Assessment

\section{InTRODUCTION}

The Galapágos Islands are a group of basaltic shield volcanoes related to a hotspot that currently lies 170 $\mathrm{km}$ south of the Galápagos Spreading Center [Allan and Simkin 2000]. The western volcanoes located on Isabela and Fernandina islands show frequent activity with approximately 69 eruptions reported since the early 1800s [Global Volcanism Program 2013c]. For instance, Fernandina volcano has had at least 28 historical eruptions [Global Volcanism Program 2013a] including one in 2017 and 2018, and Sierra Negra had 13 [Global Volcanism Program 2013b] including one in 2018. Nonetheless, geophysical studies have been

*Corresponding author: fjvasconez@igepn.edu.ec limited due to the islands' remote location [Rowland et al. 2003; Chadwick et al. 2011] and also because the only permanent human settlement in the area is the small town of Puerto Villamil at the south of Isabela. Thus, according to Rowland et al. 2003, p. 314 "many of the eruptions have gone unnoticed [...]. Although the human population has grown, access to eruption sites is still difficult". Only since the 1990s have eruptions been systematically observed and instrumentally monitored [e.g. Allan and Simkin 2000; Rowland et al. 2003; Chadwick et al. 2011; Geist et al. 2008; Bagnardi et al. 2013; Bernard et al. 2015; Xu et al. 2016].

In 2014, Instituto Geofísico (IG-EPN) installed new broadband seismometers on Fernandina (2) and Isabela (4), allowing a much better follow-up of the activity and for the first time allowing the study of seismic unrest 
in detail. This Report presents an overview of the time series (seismic, ground deformation, $\mathrm{SO}_{2}$, thermal) before and during recent eruptions in Galápagos (2017 and 2018 Fernandina eruptions and 2018 Sierra Negra). This information allows us to illustrate significant differences between those volcanic systems and their behavior.

\section{SUMMARY OF THE ERUPTIONS}

The following summary is set in Coordinated Universal Time (UTC) which for Galápagos Archipelago means UTC-6 (local time).

\subsection{Fernandina (Fernandina Island)}

After 8 years of quiescence, Fernandina $\left(0.37^{\circ} \mathrm{S}\right.$, $91.55^{\circ} \mathrm{W}, 1476 \mathrm{~m}$ a.s.l.), the westernmost volcano of the Galápagos Archipelago began a new eruptive phase on 4 September 2017. At $11 \mathrm{~h} 34$ the IG-EPN monitoring network detected an increase in hybrid seismic events, which presented an energy peak at $16 \mathrm{~h} 20$. Seismic signals changed at $17 \mathrm{~h} 25$ from hybrid to low-frequency events (LF) and finally at $18 \mathrm{~h} 25$ volcanic tremor was recorded. This tremor was associated with the beginning of the eruption and extrusion of lava flows (Figure 1A). Additionally, Interferometric Synthetic Aperture Radar (InSAR) detected uplift of 17 centimeters from March 2015 to September 2017 on the floor of the caldera $\left(31 \mathrm{~km}^{2}\right)$, the final five centimeters of which occurred in the last two months before the eruption [IGEPN 2017].

The first thermal anomaly detected by GOES-16 satellite was at $18 \mathrm{~h} 30$ close to the caldera rim, five minutes after the onset of the eruption based on volcanic tremor (Figure 1A). The eruption generated a column that reached $4000 \mathrm{~m}$ a.s.l., composed mainly of volcanic gases with low ash content drifting to the west. The eruption originated from a three-kilometer-long arcuate fissure located on the southwestern upper-flank of the volcano, at the same location as the 2005 eruption [Chadwick et al. 2011; Bagnardi et al. 2013]. The fissure emitted several lava flows that covered an area of $6.5 \mathrm{~km}^{2}$ (Figure 2). The maximum run-out of the flows was four kilometers downslope. These lava flows did not reach the ocean. After two and a half days, a decrease in the seismic energy back to background levels indicated that the eruption concluded (Figure 1A). $\mathrm{SO}_{2}$ degassing was clearly seen by OMI and OMPS satellite instruments. The highest $\mathrm{SO}_{2}$ mass observed by OMPS was on September 5, reaching $8.2 \times 10^{6} \mathrm{~kg}$.

The most dangerous hazard associated with this eruption was the series of wildfires triggered by the high temperatures of the lava flows and the prevailing surface wind direction. The fires burned an area of $16 \mathrm{~km}^{2}$ on the western flank where endemic fauna and flora were present (Figure 2). The wildfires ended one month after the eruption concluded.

On 16 June 2018, nine months after the previous eruption, a new period of unrest began. The seismic monitoring network of the IG-EPN detected nine earthquakes larger than $2.5 \mathrm{M}_{L V}$, starting at $14 \mathrm{~h} 37$, with the largest event of $4.1 \mathrm{M}_{L V}$ occurring at 15h22. At $17 \mathrm{~h} 15$ volcanic tremor was observed indicating the beginning of the eruption and lava emission (Figure 1B). The eruption occurred on the northern flank of the volcano 1.5-2 km downslope of the caldera rim (Figure 2). It produced an eruptive column of volcanic gases and low ash content drifting to the southwest that reached $3000 \mathrm{~m}$ a.s.l. The radial fissures were 100-200 meters long and extruded lava flows that reached the ocean (4 $\mathrm{km}$ run-out) and covered $1.58 \mathrm{~km}^{2}$ (Figure 2). Similar to the previous eruption, this ended two days after of the seismic activity began (Figure $1 \mathrm{~B}$ ). $\mathrm{SO}_{2}$ degassing reached a minimum of $32 \times 10^{6} \mathrm{~kg}$ according to the OMPS image of July 17 . InSAR data did not show significant deformation from September 2017 to June 2018 [Paul Lundgren personal comm.].

\subsection{Sierra Negra (Isabela Island)}

Sierra Negra volcano $\left(0.81^{\circ} \mathrm{S}, 91.13^{\circ} \mathrm{W}, 1124 \mathrm{~m}\right.$ a.s.l. $)$ is located at the southern end of Isabela Island. Its last eruption, in 2005, was characterized by the extrusion of 150 million cubic meters $\left(150 \mathrm{Mm}^{3}\right)$ of lava flows that covered a large part of the caldera floor and a smaller area to the north of the caldera [Geist et al. 2008]. According to Global Volcanism Program 2013b, Sierra Negra averages one eruptive period every 11-12 years with most of the recent activity located on the northern flank and inside its vast caldera $\left(82 \mathrm{~km}^{2}\right)$.

Since July 2017, persistent signals of unrest were detected by the IG-EPN. Thousands of earthquakes $(>15,000)$ located inside and at the rim of the caldera were recorded at shallow depths (1-15 km). Many of them were larger than $3 \mathrm{M}_{L V}$ and some even larger than $4 \mathrm{M}_{L V}$ (11 seismic events). Galápagos National Park rangers housed at the touristic rim entrance, called El Cura, regularly felt the largest earthquakes. These events also produced small rockfalls at the walls of the caldera. Most of these seismic events were volcanotectonic (VT) events, but low-frequency (LF), very lowfrequency (VLF) and hybrid events were also recorded. The number and magnitude of the seismic events increased significantly until the beginning of the eruption in June 2018.

A high-precision GPS (cGPS) network installed by UNAVCO, University of Idaho, and Oregon State University, and now maintained by Penn State University and UNAVCO, detected more than 4.5 meters of vertical uplift since 2006 (Figure $3 \mathrm{~A}$ ). InSAR images processed at the Rosenstiel School of Marine and Atmospheric Science (RSMAS, https://insarmaps.miami.edu/) confirm this result and detected a cumulative uplift of 2.46 meters on 

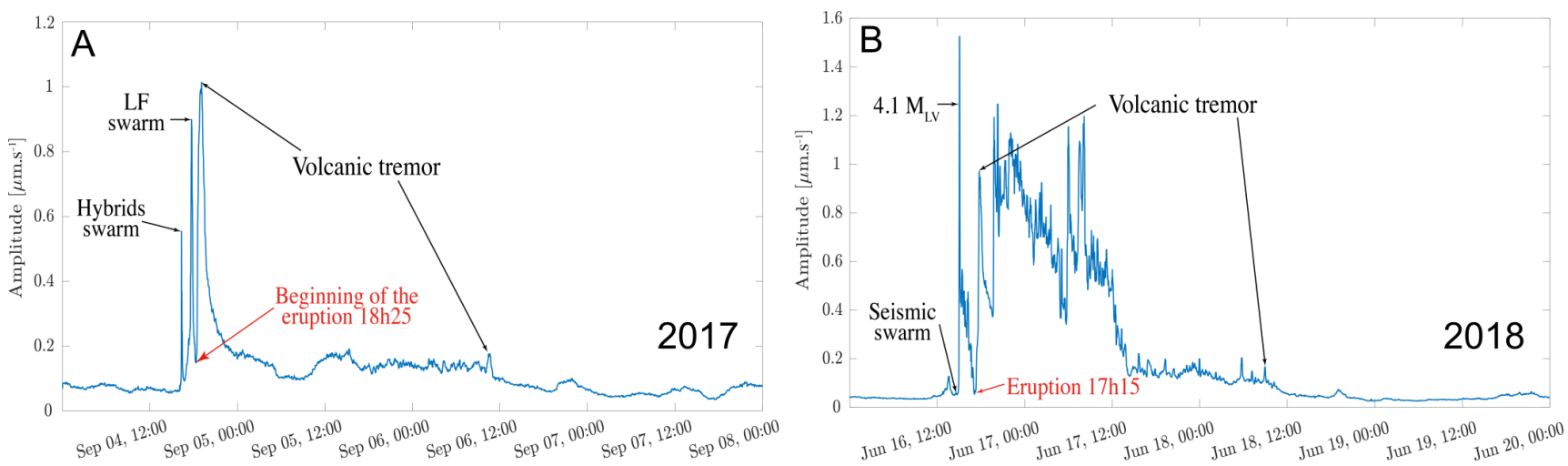

Figure 1: Median Seismic Amplitude data in 10-minute windows during two Fernandina volcano eruptions. Traces are corrected for instrument response and filtered between $1-8 \mathrm{~Hz} .:$ [A] 2017, seismic station nearest FER2 and [B] 2018, seismic station nearest FER1. See Figure 2 for the location of the seismic stations.

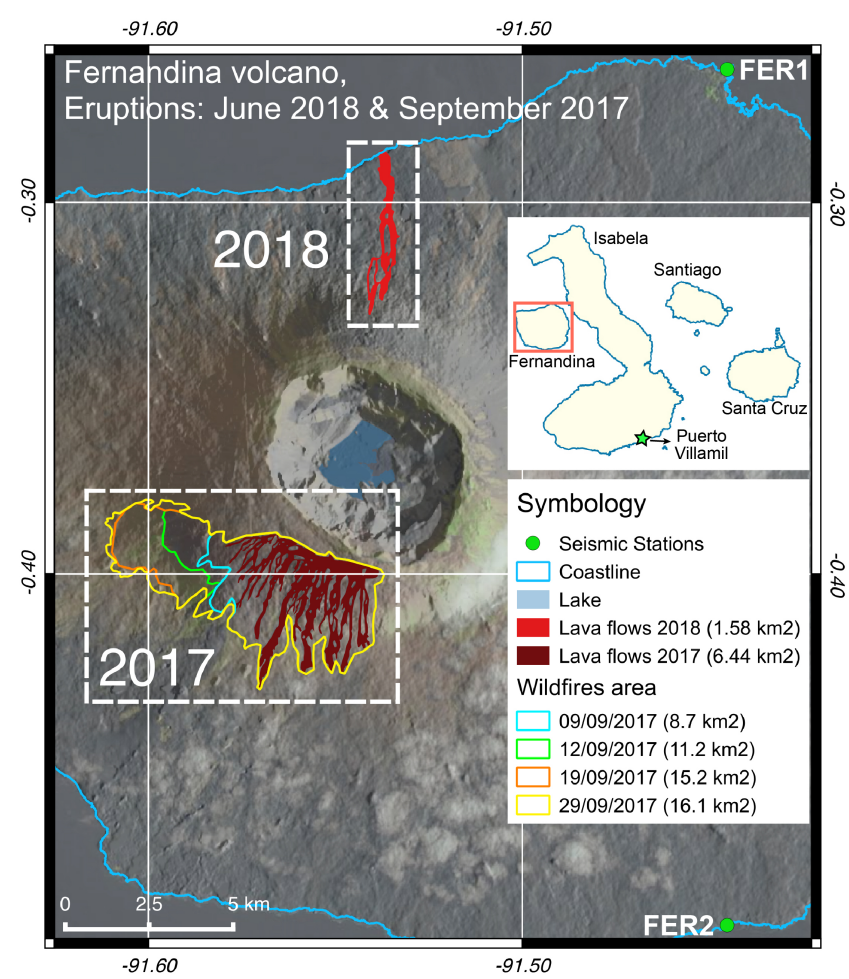

Figure 2: Map of the eruptions of Fernandina volcano in September 2017 and June 2018. Note color lines showing the area burnt by wildfires triggered by the lava flows and the prevailing wind during the 2017 eruption. Green dots are the location of the seismic stations FER1 and FER2. Data provided by: Sentinel2: 21 June, 16 July 2018 and 9, 19 and 29 Sept 2017. Landsat- 812 Sept 2017. Hillshade provided by JAXA. Inset shows the main islands of Galápagos Archipelago and the red rectangle the location of Fernandina volcano.

the center of the caldera floor since December 2014 (Figure 3B). According to the cGPS network, since January 2018 the uplift rate accelerated and was close to 11 centimeters per month.
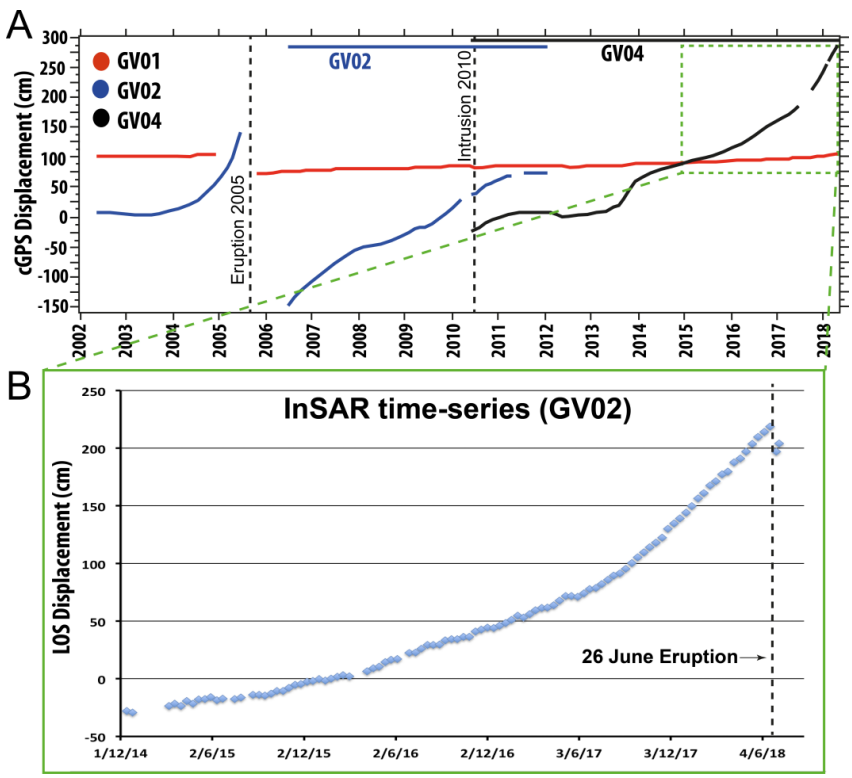

Figure 3: [A] Time-series of the vertical component for three cGPS stations on the rim (GV01) and within the caldera (GV02, GV04) at Sierra Negra provided by Penn State (see Figure 5 for locations). The cumulative uplift exceeds 4.5 meters. The cGPS stations provide high-temporal sampling of the deformation signal. [B] Green box shows the time-series inversion assessed by InSAR since 2014 on GV02's location using Sentinel-1 (128-path) taken from RSMAS (https://insarmaps.miami.edu/). Note that cGPS and InSAR trends looks similar in the same period of time. Dashed lines show important events in the volcano.

On Tuesday, 26 June 2018 at $09 \mathrm{~h} 15$, a $5.3 \mathrm{M}_{L V}$ earthquake with a focal mechanism indicating reverse slip occurred near the southwestern caldera rim at $5.3 \mathrm{~km}$ depth (Figure 4A, Figure 5). This earthquake was large enough to be felt and reported by residents in nearby Puerto Villamil located $19 \mathrm{~km}$ southeast of the epicenter (see inset in Figure 5). It produced an uplift of 
the center of the caldera floor before the eruption began. After a few hours of relative seismic quiescence, at $17 \mathrm{~h} 17$, an intense seismic swarm commenced and included a $4.6 \mathrm{M}_{L V}$ earthquake and several VLF, VT and LF events embedded in the sequence. Finally, at $19 \mathrm{~h} 40$ volcanic tremor began to dominate the seismic record indicating the beginning of the eruption (Figure 4A).
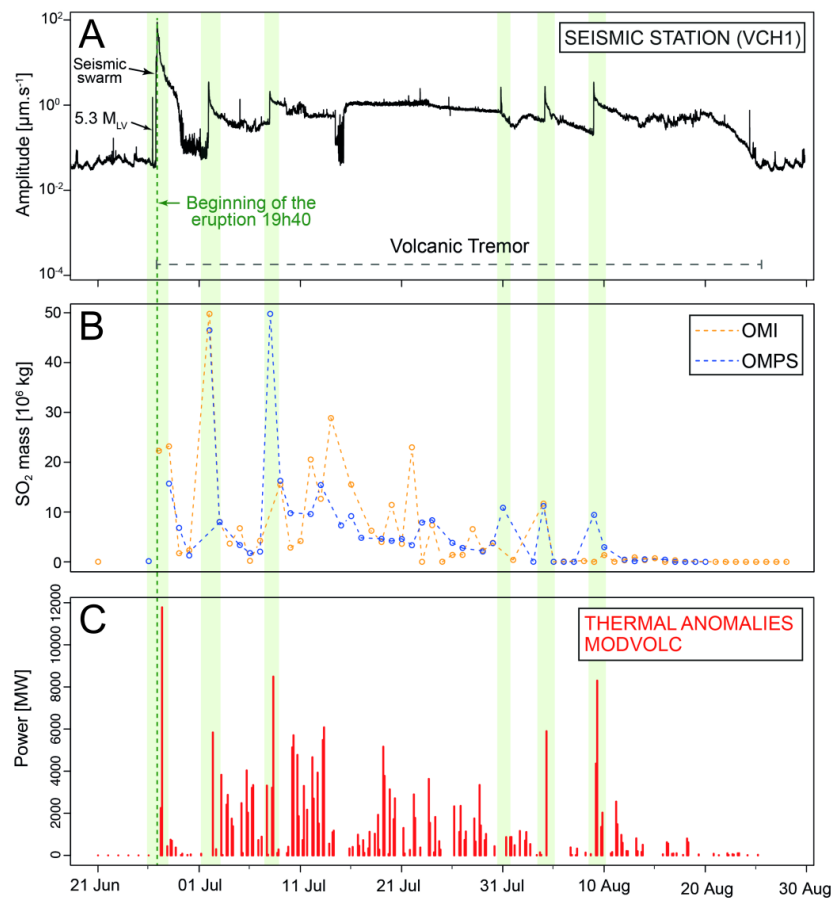

Figure 4: Composite image of the monitoring parameters at Sierra Negra volcano, from 21 June to 30 August 2018. Green dashed-line marks the beginning of the eruption and green bars show the main eruptive pulse. [A] Median Seismic Amplitude data (station VCH1, see Figure 5 for the location) in 10-minute windows are corrected for instrument response and filtered between 1 $8 \mathrm{~Hz}$. [B] Time series of $\mathrm{SO}_{2}$ mass recorded by OMI and OMPS satellite instruments. Data downloaded from https://so2.gsfc.nasa.gov/pix/daily/0718. [C] Thermal anomalies recorded by MODVOLC. Data downloaded from http://modis.higp.hawaii.edu/.

GOES-16 satellite images identified an eruptive column of volcanic gases at $10.5 \mathrm{~km}$ a.s.l. drifting to the Northwest in addition to thermal anomalies at the northern flank of the caldera.

Two main phases were recognized during the eruption, which occurred along five eruptive fissures:

1. Phase one lasted less than one day and was the most intense. During this phase, fissures 1, 2, 3, 4 and 5 were active and lava flows covered an area greater than $17 \mathrm{~km}^{2}$ (see Figure 5).

2. Phase two lasted 57 days and was focused only on fissure 4 (Figure 5). This fissure extruded several lava flows which in total covered an area of $13 \mathrm{~km}^{2}$.
Figure 5 shows the five fissures mentioned. They will be briefly described below:

- Fissure 1 (1070 m a.s.l.) is a tangential discontinuous fissure of four kilometers in length, aligned WNW to the caldera rim, and located in the Volcán Chico sector. This fissure produced a lava fountain that extruded several lava flows covering $14.7 \mathrm{~km}^{2}$ in one day of activity. The maximum run-out of these flows was seven kilometers downslope.

- Fissures 2 (700 m a.s.1.) and 3 (550 m a.s.1.) are located to the northwest and west of the caldera, three and four kilometers downslope of the rim, respectively. These fissures were approximately 250 meters long and produced lava flows that covered $2.3 \mathrm{~km}^{2}$ and $0.4 \mathrm{~km}^{2}$, respectively, in a single day of eruptive activity.

- Fissure 4 (100 $\mathrm{m}$ a.s.l.), is located on the northwestern flank at 7-8 km north of the caldera rim, and was the most active and the only vent with ongoing activity during all the eruptive period (58 days). The most recent data indicates that flows covered an area of $13.3 \mathrm{~km}^{2}$. Most of the volume of the eruption is concentrated in this flat area. According to Sentinel-1 data collected on 6 July, lava flows reached the ocean and began to change the Ecuadorian coastline. Important hazards associated with this phenomenon were explosions due to rapid evaporation as the hot lavas enter the cold ocean. Until 25 August, the Ecuadorian territory increased about $1.5 \mathrm{~km}^{2}$.

- Finally, fissure 5 (840 $\mathrm{m}$ a.s.l.), is located to the west $1.5 \mathrm{~km}$ downslope of the caldera rim [Marco Bagnardi personal comm.]. It is 170 meters long and produced $0.026 \mathrm{~km}^{2}$ of lava flows at the beginning of the eruption.

Until 25 August, we estimated that the lava emitted by this eruption covered a total area of $30.6 \mathrm{~km}^{2}$, which is equivalent to the area occupied by Cuenca, the third largest city in Ecuador.

Additionally, the seismic record showed five eruptive pulses on 1-2, 7-8, 31 July and 4 and 9 August (Figure $4 \mathrm{~A}$ ). These seismic peaks were associated with the $\mathrm{SO}_{2}$ emission peaks detected by OMI and OMPS satellite instruments. The highest values were registered at the beginning of the eruption $29 \times 10^{6} \mathrm{~kg}$, and on July 2 and 8 , with values of $46 \times 10^{6} \mathrm{~kg}$ and $50 \times 10^{6} \mathrm{~kg}$ respectively (Figure 4B). Daily values were typically higher than $3 \times 10^{6} \mathrm{~kg}$. These pulses were also recorded by the MODVOLC system, which detected the evolution of thermal anomalies (Figure 4C). The pulses could be related to an increase in the eruptive emission rate of lava flows at fissure 4, which formed a scoria cone (200 meters width). 


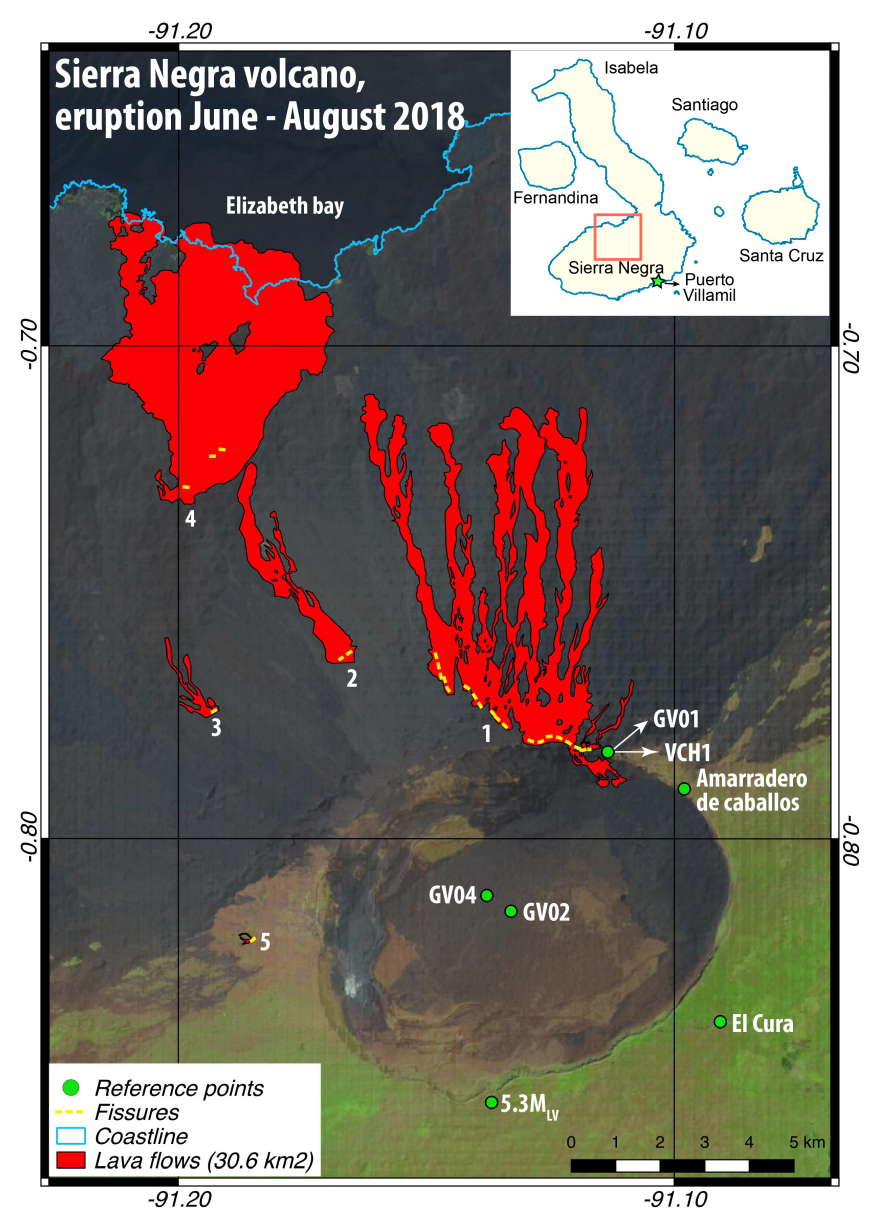

Figure 5: Map of 2018 Sierra Negra eruption (updated until 19 September 2018). Green dots are the main reference locations, which include cGPS and seismic permanent stations, epicenter of the earthquake $\mathrm{M}_{L V} 5.3$ and the Amarradero de caballos which is a place where tourists have a panoramic view of the caldera during quiescence periods. Access to this area was forbidden during pre-eruptive and eruptive period. Data provided by: Landsat-8: 27 June, 13 July and Sentinel-2: 6, 11, 16 and 31 July, 5, 10 and 25 August and 9 and 19 September 2018. Inset shows the main islands of the Galápagos Archipelago and the red rectangle the location of Sierra Negra volcano.

\section{SIZE OF THE ERUPTIONS}

The two principal quantities to define the size of volcanic eruptions are the magnitude (the mass of the material erupted) and the intensity (the mass eruption rate "MER"). According to Pyle 2015, magnitude and intensity are logarithmic-scales to describe and compare historic, pre-historic, and geological events. Since it is very difficult to quantify the intensity fluctuation of pre-historic and geological eruptions of which neither reports nor direct observations are available, intensity is likely to be a time-averaged estimate based on total erupted mass and duration [Pyle 2015].
Table 1 shows the parameters calculated for the size of the eruptions of Fernandina and Sierra Negra since 1979 to present. In 2018 the Fernandina eruption extruded a bulk volume of $7.92 \pm 4$ million $\mathrm{m}^{3}$ assuming $5 \pm 2.5$ meters thickness and had a magnitude of $3.2 \pm 0.2$ and intensity of $8 \pm 0.2$. On the other hand, the 2017 eruption extruded a volume of $13 \pm 6.5$ million $\mathrm{m}^{3}$ assuming $2 \pm 1$ meters thickness based on the similarities of area, fissure location and eruptive behavior of the 2005 Fernandina's eruption [Chadwick et al. 2011]. Thus, the 2017 Fernandina eruption had a magnitude of $3.4 \pm 0.2$ and intensity of $8.1 \pm 0.2$. In 2018 Sierra Negra erupted $189 \pm 94$ million $\mathrm{m}^{3}$ (bulk volume), assuming $3 \pm 1.5$ meters thickness on fissures 1,2 , and $3,1 \pm 0.5$ meters thickness in fissure 5 , and $10 \pm 5$ meters on fissure 4 based on [Geist et al. 2008; Reynolds et al. 1995]. This would correspond to a magnitude of $4.6 \pm 0.2$ and intensity of $7.8 \pm 0.2$.

Finally, taking into account the two phases described for the 2018 Sierra Negra eruption, it was possible to quantify the intensity of each phase. Thus, phase one had an intensity of $9.1 \pm 0.2$ and phase two of $7.8 \pm 0.2$. The higher intensity of the first phase is compatible with the higher pulses of energy detected by the seismic stations.

\section{Conclusions}

Fernandina and Sierra Negra are both shield volcanoes fed by magma from the same hot spot, which showed similar eruptive style. Nonetheless, their unrest periods reported here were quite different.

It seems that Sierra Negra usually shows a clear and long-lasting unrest period characterized by an increase in the number and magnitude of volcanic earthquakes and is also accompanied by significant ground deformation (up to few meters) of the caldera floor (i.e., 2005 and 2018 eruptions). Moreover, the $\mathrm{M}_{L V} 5.3$ earthquake was a clear precursor of the eruption, which was also the case in 2005 [Geist et al. 2008]. On the other hand, Fernandina volcano displayed short-lasting seismic unrest (few hours) and less impressive ground deformation (few centimeters) in the last two eruptions (2017 and 2018). Also, vents and fissures open up on different flanks of the volcano, which is more difficult to anticipate for the hazard assessment.

These eruptions show that long-lasting unrest periods could be related with long-lasting eruptive periods (58 days in the case of Sierra Negra volcano). On the other hand, short-lasting unrest in Fernandina volcano produced short eruptive periods (two days). This observation has a direct correlation with the volume of magma erupted, the intensity of the eruption and the risk assessment. Nonetheless, this observation requires more detailed studies, specially given that Wolf volcano (Galápagos) showed a short unrest period and long-lasting eruption [Bernard et al. 2015]. 
Table 1 - Comparison of the size of the eruptions of Fernandina and Sierra Negra volcanoes. The parameters were taken from Bourquin et al. 2009 (2009-eruption), Chadwick et al. 2011 (2005), Rowland et al. 2003 (1995), Chadwick et al. 1991 (1988) in the case of Fernandina and from Geist et al. 2008 (2005-eruption) and Reynolds et al. 1995 (1979) in the case of Sierra Negra. Moreover, based on past literature an average thickness $( \pm 50 \%$ error), a rock density of $3000 \mathrm{~kg} \mathrm{~m}^{-3}$ and deposit density (25\% void) were assumed.

\begin{tabular}{lccccccccc}
\hline Parameter & \multicolumn{4}{c}{ Fernandina } & \multicolumn{4}{c}{ Sierra Negra } \\
\hline Eruption date & 2018 & 2017 & 2009 & 2005 & 1995 & 1988 & 2018 & 2005 & 1979 \\
Area $\left(10^{6} \mathrm{~m}^{2}\right)$ & 1.58 & 6.5 & 6.7 & 9.4 & 6.5 & 3.7 & 30.6 & 18.3 & 275 \\
Average thickness $(\mathrm{m})$ & $5 \pm 2.5$ & $2 \pm 1$ & 8.5 & 2 & 8.5 & 5 & $1,3,10$ & 10 & 3 \\
Volume $\left(10^{6} \mathrm{~m}^{3}\right)$ & $7.92 \pm 4$ & $13 \pm 6.5$ & 57.0 & 18.8 & 55.3 & 20 & $189 \pm 94$ & 150 & 900 \\
DRE $\left(10^{6} \mathrm{~m}^{3}\right)$ & $5.9 \pm 3$ & $9.7 \pm 4.9$ & 42.7 & 14.1 & 42.0 & 15 & $141 \pm 71$ & 113 & 675 \\
Erupted Mass $\left(10^{10} \mathrm{~kg}\right)$ & $1.78 \pm 0.9$ & $2.9 \pm 1.5$ & 12.8 & 4.23 & 12.6 & 4.5 & $42.4 \pm 21$ & 33.8 & 203 \\
Duration $($ days $)$ & 2 & 2.5 & 18 & 16 & 73 & 3 & 58 & 8 & 60 \\
MER $\left(\mathrm{m}^{3} \mathrm{~s}^{-1}\right)$ & $34.4 \pm 17$ & $45.1 \pm 22.6$ & 27.46 & 10.2 & 6.66 & 57.87 & $28.2 \pm 14$ & 162.76 & 130.21 \\
Magnitude & $3.2 \pm 0.2$ & $3.4 \pm 0.2$ & 4.11 & 3.63 & 4.1 & 3.65 & $4.6 \pm 0.2$ & 4.56 & 5.31 \\
Intensity & $8 \pm 0.2$ & $8.1 \pm 0.2$ & 7.9 & 7.5 & 7.3 & 8.2 & $7.8 \pm 0.2$ & 8.7 & 8.6 \\
\hline
\end{tabular}

The areas covered by lava flows during 2018 Sierra Negra eruption was of approximately $30.6 \mathrm{~km}^{2}$ in 58 days while in Fernandina eruptions the covered areas were of $1.58 \mathrm{~km}^{2}$ (2018) and $6.5 \mathrm{~km}^{2}$ (2017) in two days each.

Galápagos Archipelago is a fragile ecosystem with unique native flora and fauna. Both can be highly threatened by lava flows and wildfires as occurred during the Fernandina eruption in 2017.

Satellite images provided critical information for hazard assessment and unrest and eruption monitoring in such remote areas. Freely available satellite data complement the monitoring networks of volcanic observatories and help to improve the communication with the stakeholders.

\section{Acknowledgements}

The information presented in this Report was based on the special reports of the Instituto Geofísico (www.igepn.edu.ec). The authors thank all scientists who analyzed and interpreted the results presented in this article. Special acknowledgement to all the team of the IG-EPN and all the staff of Galápagos National Park especially to Gabriela Vivas, Oscar Carvajal and Leonardo García. We also thank to the international partners such as: InSAR data analysis provided by Rosenstiel School of Marine and Atmospheric Science and California Institute of Technology (USA), and University of Oxford and Cambridge (UK), and cGPS analysis provided by The Pennsylvania State University (USA). We also thank to all free-online satellite plataforms such as: RAMMB Slider-Colorado State University, EarthExplorer, Landviewer, Sentinel-hub, MODVOLC, MIROVA and Global Sulfur Dioxide Mon- itoring by NASA. This report has been conducted in the context of the Proyecto de Generación de Capacidades para la Emisión de Alertas Tempranas de la SENPLADES.

\section{Author CONTRibutions}

Francisco Vasconez, Patricio Ramón, Silvana Hidalgo and Benjamin Bernard used satellite images to monitor the evolution of the eruption, which include thermal anomalies, lava flows emplacement, ash columns, degassing patterns, ground deformation and secondary hazards. Stephen Hernandez, Mario Ruiz and Alexandra Alvarado analyzed and interpreted the seismic data of the unrest and eruptive period of these eruptions. Peter La Femina and Gorki Ruiz collected and analyzed the cGPS data.

Francisco Vasconez, Silvana Hidalgo, Benjamin Bernard, Stephen Hernandez, Peter La Femina, Patricio Ramón, Mario Ruiz and Alexandra Alvarado led the writing of the manuscript, with contributions from all authors.

\section{Data AVailability}

Thermal anomalies (http://modis.higp.hawaii.edu/, http://www.mirovaweb.it/), multispectral satellite images (Sentinel-2 and Landsat- 8 https://www.sentinelhub.com/, https://eos.com/landviewer/, https://earthexplorer.usgs.gov), radar images (Sentinel-1, https://vertex.daac.asf.alaska.edu/), degassing data (https://so2.gsfc.nasa.gov/), and InSAR ground-deformation (https://insarmaps.miami.edu/) were provided by several free-online platforms. Seismic and cGPS data recorded by IG-EPN and Penn 
University and UNAVCO can be requested for further analysis and future work at https://www.igepn.edu.ec/ and http://www.unavco.org/ respectively.

\section{Copyright Notice}

(c) The Author(s) 2018. This article is distributed under the terms of the Creative Commons Attribution 4.0 International License, which permits unrestricted use, distribution, and reproduction in any medium, provided you give appropriate credit to the original author(s) and the source, provide a link to the Creative Commons license, and indicate if changes were made.

\section{REFERENCES}

Allan, J. F. and T. Simkin (2000). "Fernandina Volcano's evolved, well-mixed basalts: Mineralogical and petrological constraints on the nature of the Galapagos plume". Journal of Geophysical Research: Solid Earth 105.B3, pp. 6017-6041. DOI: 10.1029 / 1999 jb900417.

Bagnardi, M., F. Amelung, and M. P. Poland (2013). "A new model for the growth of basaltic shields based on deformation of Fernandina volcano, Galápagos Islands". Earth and Planetary Science Letters 377-378, pp. 358-366. DoI: 10.1016/ j eps1.2013.07.016.

Bernard, B., H. Wright, P. Ramon, A. Guevara, S. Hidalgo, D. Pacheco, D. Narváez, and F. Vásconez (2015). "Preliminary Results on the 2015 Eruption of Wolf Volcano, Isabela Island, Galápagos: Chronology, Dispersion of the Volcanic Products, and Insight into the Eruptive Dynamics". AGU Fall Meeting Abstracts. V31B-3022.

Bourquin, J., S. Hidalgo, B. Bernard, P. Ramón, S. Vallejo, and A. Parmigiani (2009). Fernandina volcano eruption, Galápagos Islands, Ecuador: SO2 and thermal field measurements compared with satellite data: Informal report, Instituto Geofísico Escuela Politécnica $\mathrm{Na}$ cional (IGEPN).

Chadwick, W. W., S. Jónsson, D. J. Geist, M. Poland, D. J. Johnson, S. Batt, K. S. Harpp, and A. Ruiz (2011). "The May 2005 eruption of Fernandina volcano, Galápagos: The first circumferential dike intrusion observed by GPS and InSAR". Bulletin of Volcanology 73.6, pp. 679-697. Dor: 10.1007 / s00445010-0433-0.
Chadwick, W. W., T. D. Roy, and A. Carrasco (1991). "The September 1988 intracaldera avalanche and eruption at Fernandina volcano, Galapagos Islands". Bulletin of Volcanology 53.4, pp. 276-286. Dor: 10 . $1007 / \mathrm{bf} 00414524$.

IG-EPN (2017). Informe Especial del Volcán Fernandina $N^{\circ} 02$.

Geist, D. J., K. S. Harpp, T. R. Naumann, M. Poland, W. W. Chadwick, M. Hall, and E. Rader (2008). "The 2005 eruption of Sierra Negra volcano, Galápagos, Ecuador". Bulletin of Volcanology 70.6, pp. 655-673. DOI: $10.1007 / \mathrm{s} 00445-007-0160-3$.

Global Volcanism Program (2013a). [Fernandina (353010)] in Volcanoes of the World, v. 4.7.1. Venzke, E (ed.). Smithsonian Institution. URL: https : / / volcano. si . edu/volcano. cfm? vn=353010 (visited on 10/02/2018).

- (2013b). [Sierra Negra (353050)] in Volcanoes of the World, v. 4.7.1. Venzke, E (ed.). Smithsonian Institution. URL: https: // volcano. si . edu/volcano. cfm? vn= 353050 (visited on 08/06/2018).

- (2013c). Volcanoes of the World, v. 4.7.1. Venzke, E (ed.). Smithsonian Institution. URL: https : / / volcano.si.edu (visited on 10/02/2018).

Pyle, D. M. (2015). "Sizes of volcanic eruptions". The Encyclopedia of Volcanoes. Ed. by H. Sigurdsson, B. Houghton, S. McNutt, H. Rymer, and J. Stix. Elsevier, pp. 257-264.

Reynolds, R. W., D. Geist, and M. D. Kurz (1995). "Physical volcanology and structural development of Sierra Negra volcano, Isabela Island, Galápagos archipelago". Geological Society of America Bulletin 107.12, pp. 1398-1410. DoI: 10 . $1130 / 0016$ 7606 (1995) 107<1398: pvasdo>2.3. co;2.

Rowland, S. K., A. J. L. Harris, M. J. Wooster, F. Amelung, H. Garbeil, L. Wilson, and P. J. MouginisMark (2003). "Volumetric characteristics of lava flows from interferometric radar and multispectral satellite data: the 1995 Fernandina and 1998 Cerro Azul eruptions in the western Galapagos". Bulletin of Volcanology 65.5, pp. 311-330. DOr: 10 . 1007 / s00445-002-0262-x.

Xu, W., S. Jónsson, J. Ruch, and Y. Aoki (2016). "The 2015 Wolf volcano (Galápagos) eruption studied using Sentinel-1 and ALOS-2 data". Geophysical Research Letters 43.18, pp. 9573-9580. Dor: 10.1002 / $2016 \mathrm{~g} 1069820$. 